\title{
Research
}

\section{Linking Land Change with Driving Forces and Actors: Four Conceptual Models}

\author{
$\underline{\text { Anna M. Hersperger }}^{1}, \underline{\text { Maria-Pia Gennaio }}^{2}$, Peter H. Verburg $^{3}$, and Matthias Bürgi $^{1}$
}

\begin{abstract}
Models in land change research are often chosen arbitrarily based on practical rather than theoretical considerations. More specifically, research on land change is often based on a research framework with three crucial elements - driving forces, actors, and land change - in an ad hoc and casespecific configuration. The lack of solid and widely applicable concepts about the conceptual link between these three elements can negatively affect individual research projects and hamper communication and generalizations beyond the individual project. We present four basic models for linking land change with driving forces and actors. These models are illustrated with examples from the research literature. Based on the main characteristics of the models and practical considerations, we propose guidelines for choosing among the four models for specific studies. More generally, we want to raise awareness that land change research is especially demanding with respect to conceptual backgrounds and that conceptual considerations will help improve the scientific quality of individual studies as well as their potential contribution towards generic theories of land change.
\end{abstract}

Key Words: conceptualization; guidelines; land change modeling; land cover change; land use; model selection; organizational heuristic

\section{INTRODUCTION}

Understanding the causes and consequences of land change is one of the prime goals of global change research (Lambin et al. 2003, Rindfuss et al. 2004, Lambin and Geist 2006). Consequently, land change has become an important research topic in the last decade (Turner et al. 2007, Turner and Robbins 2008). The aim of land change science is to understand the biophysical and human causes of land use and land cover change, and the land use and land cover patterns and dynamics affecting the structure and function of the earth system (Rindfuss et al. 2004).

Theory, observations, and models are all crucial components of land change research. Theory denotes knowledge, i.e., a system of thought or a set of connected statements, used in the process of explanation (Walker 2001, Walker and Solecki 2004). Models are tools that support the analysis of the causes and consequences of land use change (Verburg et al. 2004). Theory is indispensable in meaningful model building since models need to be based on a conception and explanation of reality, i.e., a theory (Briassoulis 2000, Lambin et al. 2006). The analysis of land use change is no exception. Since land change research is a relatively young science, it can benefit from further advances in both theory and modeling.

In this paper, we present an organizational heuristic with four conceptual models for linking land change with driving forces and actors. This input is expected to enhance the potential contribution of land change studies to theory development and to improve communication and generalization beyond the individual project.

Though a unifying theory of land change does not yet exist (Lambin and Geist 2006, Turner et al. 2007), significant theoretical advances have been made in land change science (Walker and Solecki 2004). A review of land change theories is, for example, provided by Briassoulis (2000), Lambin et al. (2006), and VanWey et al. (2005) (for forest 
ecosystems). Theory generally comes from one of the associated fields that deal with the interaction of humans with their environment (e.g., economy, sociology, political ecology, and social psychology). Three main traditions of theorizing land use change can be distinguished: urban and regional economics and regional science, sociological and political economy, and nature-society theories (Briassoulis 2000). Despite recent interest in the nature-society theories, von Thünen's agricultural land rent and Alonso's urban land rent theories still dominate land change research (Chomitz and Gray 1996, Walker 2004). They are used either independently or in conjunction with other theories such as Chayanov's theory of the peasant economy, Boserup's thesis (Boserup 1965), and historical analysis (Angelsen 1999, Geoghegan et al. 2001, Irwin and Geoghegan 2001, Perz and Walker 2002, Walker 2004, Caldas et al. 2007). For example, Walker and Solecki (2004), based on Walker (2001), unite the bid rent model of von Thünen and urban theorists with historical analysis in order to account for the loss of wetlands in South Florida. The sociological and political economy approach refers to theories that emphasize the importance of human agency, social relationships, social networks, and socio-cultural change. For example, Rudel's sociological perspective on urban sprawl and tropical deforestation emphasizes the role of strategic actions by states and coalitions of interested parties in transforming landscapes, and identifies agents of change and the timing of transformative events (Rudel 2009). Overmars et al. (2007a) formalize the explanation of human decision and action in the environmental field with the action-in-context (AiC) framework. The sociological and political economy approach can be especially powerful for land change research in combination with the economic approach (e.g., Walker et al. 2009). Nature-society theories refer to a holistic view of the human causes of environmental change and deal with the totality of interactions between natural environment, economy, society, technology, and culture. Examples of these approaches are the frontier thesis (Richards 1990), general system theory (Merchant 1990), and complexity theory (Manson 2001, Manson and O'Sullivan 2006, Parker et al. 2008, Rindfuss et al. 2008).

Despite recent progress, there are fundamental reservations about whether we ever will have (or agree on) a unified theory of land change (Lambin et al. 2006). Several authors have suggested using a synthesis of theories rather than relying on a single theoretical schemata (Lambin et al. 2006, Briassoulis 2008). This suggestion is supported by Clifford's observation of the recent development towards a situation of methodological and philosophical pluralism (Clifford 2008).

Many research strategies can support further theory development, including inductive and deductive approaches. Though many studies geared at understanding the causes of land change so far are inductive (overviews by Walker et al. [2002] and Verburg et al. [2004]), they are sometimes guided by theory without testing the theory as such (Overmars et al. 2007a). Recently, the gain of theory development through deductive approaches has been pointed out and demonstrated (e.g., Walker and Solecki 2004, Overmars et al. 2007b). Clearly, further theory development can benefit from inductive and deductive approaches as well as close interaction with model development.

Land change models are tools that support the analysis of the causes and consequences of land use changes in order to better understand the functioning of the land use system and to support land use planning and policy (Verburg et al. 2004). Land use models can be used to test theory by exploring to what extent theoretical relations correspond to reality (Matthews et al. 2007, Browder et al. 2008). At the same time, land use models are used to explore the effects of possible future changes in driving factors on land use. In this sense, models are used to provide ex-ante assessments of policies or serve as an early warning system for environmental impacts (Verburg et al. 2006a, Rounsevell et al. 2006). Many models and model classification schemes exist (e.g., Agarwal et al. 2002, Schaldach and Priess 2008). Many models are descriptive models (which simulate the functioning of the land use system and the spatially explicit layout of near future land use patterns, sensu Verburg et al. 2004) in contrast to prescriptive models (which aim at the calculation of optimized land use configurations that best match a set of goals and objectives). This understanding of descriptive models includes prediction, an issue very important for the use of models for policy development and planning. If models are to support land use planning and decisions, the model is not the end, but the model-output is used in further studies (e.g., outputs of models can be used in ecological studies).

Though the science of land change is still evolving, there is agreement that a few building blocks are 
crucial: driving forces, actors, and land change. We define land change as the result of proximate causes (the direct actions) and underlying driving forces (indirectly affecting land change) (see also Geist and Lambin 2002). The study of the underlying driving forces - or simply driving forces - has a long tradition in geography and landscape research (Bürgi et al. 2004). Increasingly, land change research is broadening its approach to assess the decisions of people and institutions that execute these actions (often called actors or agents) (e.g., Baudry et al. 1999, Lambin et al. 2001). Consequently, a prevalent research question is how various driving forces and actors together affect land change and how the link between the three elements can be conceptualized. In both theory and modeling, links between the three elements are considered. However, not all authors specify in their studies how these building blocks relate to each other. Only few researchers explicitly refer to a framework, e.g., Brandt et al. (1999), Seabrook et al. (2006), Overmars et al. (2007a), and Valbuena et al. (2008). We are convinced that further progress in land change science could be fostered by developing conceptual models that link land change with driving forces and actors.

The organizational heuristic presented in this paper is based on the interrelations of the three main components - driving forces, actors, and land change. We suggest that several conceptual models are needed to reflect the wide range of study aims, research questions, systems under study, and limitations set by available data and other resources. We therefore present four basic conceptual models to represent the relationship of land change, driving forces, and actors in land change studies. While the actual link between drivers and actors or between actors and land change should be supported by theories, this simple heuristic aims at clarifying the conceptual models that underlie different approaches of land change analysis.

Traditionally, two approaches have been proposed to characterize land change: an anthropologic, process-oriented approach based on household surveys, and a land evaluation, pattern-based approach based on remote sensing and census data (Geoghegan et al. 1998, Castella and Verburg 2007, Overmars et al. 2007a,b). The distinction between the two basic approaches can be traced back to Coleman (1990) and it explains the main differences in research approaches within the land change research community in the last century. Recently, research approaches have begun to combine different approaches, often in integrated studies (Overmars et al. 2007b, Pan and Bilsborrow 2005). The organizational heuristic with the four conceptual models acknowledges this development by identifying the combination of different approaches in a single research strategy as a combination of two or more conceptual models.

\section{FOUR MODELS TO LINK LAND CHANGE WITH DRIVING FORCES AND ACTORS}

Before discussing the four models, we clarify the three core components of these models, namely driving forces, actors, and land change. Driving forces are the forces that - together with actors shape land change. Driving forces form a complex system of dependencies and interactions and affect a whole range of temporal and spatial levels. It is therefore challenging to adequately analyze them and quantify their contribution to change. Bürgi et al. (2004) identified five groups of driving forces: political, economic, cultural, technological, and natural driving forces. Population (or demography) usually falls into the category of cultural driving forces but sometimes forms an additional group (e.g., Bolstad et al. 1998, Pahari and Murai 1999).

Actors make decisions, act accordingly, and influence other actors and the environment with their actions. Actors can be individuals, agencies, and institutions, representing the whole range of organizational scales (sensu Bürgi et al. 2004). We distinguish between two types of actors: actors that affect driving forces and actors that directly change land. Examples of actors that affect driving forces, such as policies and markets, are political parties and administrative entities. Actors that directly change land are, for example, farmers or urban investors. Analogous to the proximate causes and underlying driving forces by Geist and Lambin (2002), they can be called actors in proximate causes and actors of underlying drivers. The same actor can of course, be an actor in proximate causes (e.g., as an urban investor) and an actor of underlying drivers (e.g., through his/her political activities in the context of designing planning regulations). Generally, actors are to some degree autonomous and therefore control their own actions. They often share an environment through communication and interaction. The focus of this manuscript is on the actors in proximate causes. For practical purposes, we refer to them simply as actors. 
Land change refers to change in land cover or land use. Examples are change in forest cover or conversion of traditional grassland to intensively used grassland. Land change is measured by comparing land cover/land use at two or more ponits in time. Whereas the term land change clearly refers to developments, driving forces do not necessarily have to cause change. Driving forces can be too weak, i.e., below the threshold at which change would take place, they can have a stabilizing effect (e.g., zoning regulations), or several driving forces can operate in opposite directions. All three effects result in persistence of land (Bürgi et al. 2004). The study of persistence and the related driving forces deserves much attention. The conceptual approaches we propose are equally suitable to study land change and land persistence.

Based on the analysis of a wide range of land change studies, we propose in the following sections to distinguish four distinct models for conceptualizing the link among land change, driving forces, and actors (Fig. 1). We present the models by the questions addressed, provide examples from the literature, and describe the models' strengths and weaknesses.

\section{Model Driving Force-Land Change (DF-C)}

\section{Model description and questions addressed}

In the DF-C model, driving forces are directly related to land change. In fact, the model conceptually assumes that driving forces cause the observed land change, whereas the other three models recognize that actors ultimately cause land changes. In the DF-C model, the causal relationship between driving forces and land changes is not of prime interest. Research based on this model attempts to specifically answer questions such as "Which driving forces correlate with change?" "Which of the driving forces contribute how much to change?" The answers to such questions are then often used to model past or potential future changes.

\section{Examples}

Linking land change directly to driving forces is probably the most commonly used approach in land change science. Most research based on this model searches for correlations within large, spatially explicit data sets of potential explanatory variables. For example, based on a regression analysis, Alig et al. (2004) found that population density and income significantly contributed to the proportion of land in urban uses in the USA. Walsh et al. (1999) used statistical analysis to explore the relation between population distribution and land cover at multiple spatial resolutions in northern Thailand. Bürgi and Turner (2002) statistically determined abiotic and socioeconomic explanatory variables for land cover and land cover changes along the Wisconsin River, USA. Based on ordination analyses, Hietel et al. (2005) identified stable environmental factors (slope, elevation, soil texture) as drivers of land change in the rural German highlands. Hersperger and Bürgi (2007, 2009, 2010) used expert interviews and document analysis to identify driving forces and quantify their importance in five towns in peri-urban Switzerland. Dendoncker et al. (2007) analyzed statistical associations between drivers and land use in Belgium, explicitly accounting for spatial correlation in the data. To study deforestation (especially in the Amazon), such models have been further developed to include variables for socioeconomic conditions at the farm or household level based on data collected through household surveys (e.g., Walsh et al. 2002, Moran et al. 2003, Pan and Bilsborrow 2005). These advances have been made possible by recent improvements in remote sensing technology, geographic information systems (GIS), and global positioning systems (GPS) (Fox et al. 2003).

\section{Strength and weakness}

This model is especially useful for exploratory analyses and is applicable at several scales - from global studies to local study areas. Based on the results, links between driving forces and land changes can be hypothesized, but they need further testing to move from statistical correlations closer to causal relationships. Studies based on this model are often used to model potential future scenarios. There is a whole range of variations for this model as discussed in Overmars et al. (2007a). These variations range from an exploratory analysis fully based on statistical methods to the definition of theoretical relations that are calibrated based on empirical data. However, in all cases, the relations assumed do not explicitly address the role of actors but try to explain the effects of driving factors on land directly. Distinctions should be made between analysis of change and analysis of location, and 
Fig. 1. Four conceptual models for linking land change (C) with driving forces (DF) and actors (A) in land change studies. The models are labeled based on their characteristic components and links. To keep the diagram simple, arrows indicate only the main directions of influence.

DF-C DF-A-C DFA-C
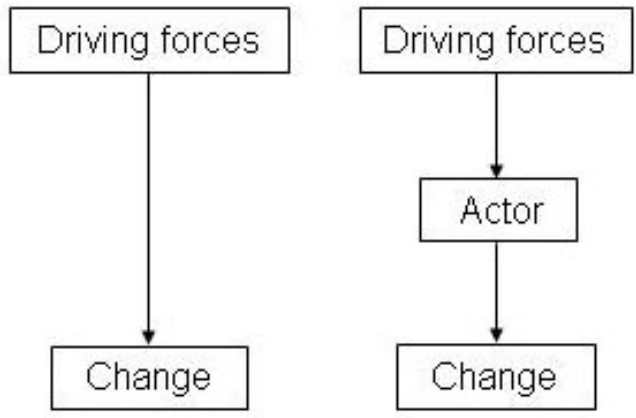

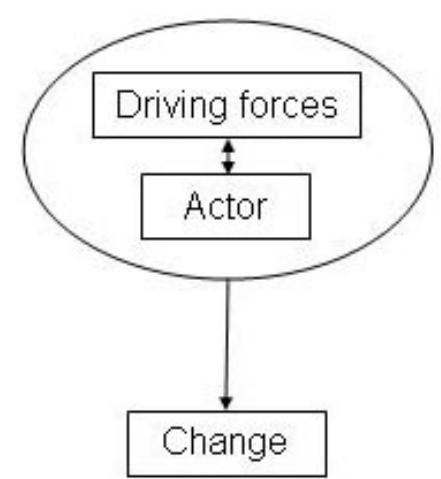

AC

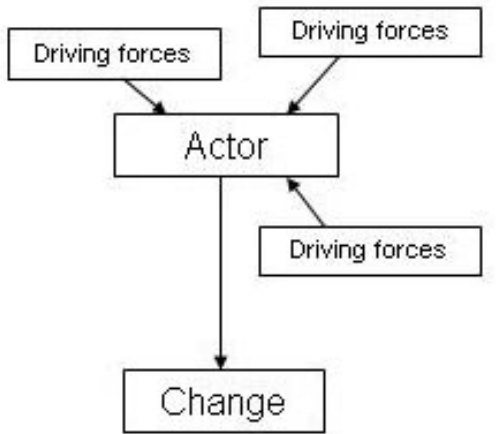

often space-time analogs are made. This conceptual model is not suited for the identification of causes of land change. If a causal understanding of land change is needed, a model that explicitly addresses the role of actors should be preferred. In addition, the DF-C model does not allow for complex interactions and feedbacks. Often, mostly linear associations and sometimes simple interactions are assumed.

\section{Model Driving Force-Actor-Land Change (DF- A-C)}

\section{Model description and questions addressed}

The conceptual model DF-A-C most clearly represents the following (often implicitly assumed) chain of events: driving forces affect actors and actors subsequently cause change. The driving forces are first and determine the actor's autonomy and motivations and therefore the actor's actions that result in change. In this model, driving forces and actors are equally important. Research based on this model attempts to answer questions such as
"Which driving forces affect actors and how do they subsequently cause change?" "What specific sequence of driving forces and actors triggers a unique land change?"

\section{Examples}

Based on expert interviews with farmers, politicians, planners, and historians, and based on document analyses, Schneeberger et al. (2007) identified actors and driving forces of detected land changes in the Swiss pre-Alps. The contribution of farmers and six other actor groups and institutions (international, national, cantonal, municipality, local planning agency, nonofficial stakeholders) to land change was analyzed. The authors found that certain constellations of actors and driving forces (unique in time and place) were especially important for change. The high number of new machine sheds built in the study area illustrates this point: the availability of new machines (technological driving force) combined with a change in farmers' attitudes towards mechanization led to a demand for additional machine sheds, and the national and cantonal subsidies eventually allowed their 
construction. Thapa and Rasul (2006) described the effect of changing national policies (political driving forces) on farmers and the farmers' reaction to these policies by changing land use practices and by migration. Document analysis was complemented with personal observations and discussions with local people. The results confirmed the hypothesis that farmers' land use decisions were influenced significantly by national policies and institutional arrangements, including laws.

\section{Strength and weakness}

The causal chain "driving forces-actors-land change" is very intuitive and efforts to explain this chain are certainly very valuable for land change science. Since both driving forces and actors are important in research based on this model, substantial data on both components are necessary. Data on actors generally involves surveys or faceto-face interviews, whereas data on driving forces generally are derived from existing biophysical and socioeconomic databases and maps. Consequently, methodological efforts to integrate the data (i.e., quantitative and qualitative data) are challenging (Rindfuss et al. 2004). Often, it is necessary to casespecifically design an appropriate combination of methods. The data requirements limit the scale of analysis. However, straightforward relations can potentially be extrapolated with the help of census data and/or large-scale farm surveys (e.g., the European Union Farm Accounting Data Network FADN).

\section{Model Driving Force/Actor-Land Change (DFA-C)}

\section{Model description and questions addressed}

In DFA-C models, driving forces and actors are in close interaction, and as a result of this interaction, change occurs. The focus is neither on driving forces nor on actors nor on the causal chain from driving forces to actors to change but on the interplay of driving forces and actors, including feedbacks. Research based on this model attempts to answer the question "How is land change a result of interacting driving forces and actors?" To answer this question, it is necessary to first analyze the question about how driving forces influence actors in their decisions and how these decisions feed back on driving forces.

\section{Examples}

Gennaio integrated a policy analysis approach (the Advocacy Coalition Framework developed by Sabatier [1998]) into driving forces research in order to study the causes of urbanization in four municipalities in the Agglo Obersee, Switzerland (Gennaio 2008, Gennaio et al. 2009). The causes of actors' urban management decisions during 19702007 were analyzed based on document analysis and interviews with the main actors. The analysis specifically focused on the effect of the major driving force, the local land use plan, on actors' decisions and the influence of the same actors on the revisions to and further development of the local land use plans. A policy evaluation based on a spatially explicit analysis of urban change was then performed to link these decisions with physical change (Gennaio 2008). The results of this study showed that the national and international environmental discourses that emerged in the $1970 \mathrm{~s}$ and the fast urban change since the 1960s strongly influenced the ideologies of the actors. Consequently, in the 1980s, the actors designed new regulations to better guide urban change. However, the local spatial configuration of existing settlements and roads and the power distribution among local actors determined how these regulations were implemented locally. Overmars et al. $(2007 a, b)$ developed a decision model, following the AiC framework of de Groot (1992). Questionnaires and semi-structured interviews with farmers and key actors were used to determine the reasons why they cultivated a certain crop at a certain location in Cagayan Valley on the island Luzon in the Philippines. The focus was on how the actors (and his/her ethnicity) interacted with explanatory factors such as slope, the presence of a creek, investments, net benefit, age, and policy variables. Özkaynak (2008) studied the interaction among global factors, local driving forces, and actors for urban development in the Yalova area, Turkey. The author used future development scenarios in participation processes to raise the local actors' awareness about the influences of global factors on local decisions.

\section{Strength and weakness}

This model focuses on a better understanding of the interaction of driving forces and actors. Such an understanding is necessary for planning and management interventions - be it top down or 
participative. Interviews and surveys based on questionnaires are the main data basis for this model. Consequently, the investigations based on this model are case studies that cover a small to medium geographical extent. The results are site specific and difficult to extrapolate in space.

\section{Model Actor-Land Change (A-C)}

\section{Model description and questions addressed}

In the A-C model, actors play the central role in land change. Though this model recognizes the existence of driving forces, they are one of the elements of the environment in which actors make their decisions. The model represents the understanding that land change is often the cumulative result of individual agents' decisions. Whereas the research in model DFA-C centers on the question "How is land change a result of the interaction of driving forces and actors?", in the model A-C, the central questions are "How does the actor's reasoning and values influence the local land use patterns?", "How do changing attitudes, biographies, and household characteristics affect land use decisions?", and "How can the decision making process of actors be modeled?" Typically, characteristic land use decision strategies of a limited number of actor types are identified and described (e.g., farmers in Valbuena et al. [2008], resident households in Fontaine and Rounsevell [2009], or government institutions in Monticino et al. [2007]).

\section{Examples}

In contrast to traditional work that is based largely on profit maximization (homo economicus), contemporary work on behavior related to land use often presumes that actors have a broad set of values that they take into account, and have incomplete access to information and weaker calculation abilities (Rabin 1998). For example, several studies identified a variety of factors that determined farmers' participation in agri-environmental schemes and the application of organic farming (e.g., Defrancesco et al. [2008] in northern Italy, Darnhofer et al. [2005] in Austria, and Herzon and Mikk [2007] in Estonia and Finland). To study land change, Bohnet et al. (2003) used a biographical analysis and demonstrated how closely related the recent history of land change was to the personal histories of the farmers who occupy and manage rural land in the English High Weald. The authors identified changing attitudes to land use as a decisive factor for land use decisions. In the wet tropics of Australia, Bohnet (2008) identified several landholder groups with distinct management strategies that have shaped land change over the past decades. Wilson (2008) suggested that it is possible to categorize different farm types (primarily based on farm ownership) along the productivist/ nonproductivist multifunctional spectrum as agents in an overall transition from weak to strong multifunctionality. The effect of actors' choice and behavior on land change has been studied particularly well in the case of the Amazon deforestation. For example, Walker et al. (2009) addressed policies that have created location rents in Amazonia, the effect of these rents on land managers, and the spatial implications of their behavior on forests.

Many agent-based models (ABMs), which are increasingly popular in land change research (Parker et al. 2002, Matthews et al. 2007, Clifford 2008), are based on the A-C model. For example, Balmann (1997) developed an ABM for the evolution of land use following German reunification. The author subsequently used the model to investigate the influence of reducing price support and introducing compensation payments on decisions related to farm size and income. Loibl and Toetzer (2001) developed an ABM in order to understand growth and densification processes in suburban Vienna. Household agents chose where to live based on factors such as small- and large-scale accessibility, land prices, landscape attractiveness, social and commercial services, and land use zoning.

\section{Strength and weakness}

This model targets the site-specific actors of land change and the effect of their decision making on land change. The model aims to represent the decision-making process in detail in order to establish causality. Important processes like changing attitudes, learning, adaptive behavior, and collective action can be incorporated into this model, whereas they are difficult to address with other conceptual models. Studies based on the A-C model often focus on a rather small geographical extent because the model relies on detailed data on actor behavior. Some of the required data can be obtained from public statistics, though sometimes data privacy is an issue. Often, however, these data are not sufficient to model behavior, and actors must 
be questioned directly. Written surveys and face-toface interviews are commonly used, but they provide data that relates to only relatively short time periods and are likely to be more subjective than standardized statistical data (Hietel et al. 2005). Most often, research based on the A-C model focuses on a limited number of actor categories. Complex systems dominated by the interplay of several actor categories such as farmers, residents, developers, and planning agencies rarely have been modeled. Their modeling remains a challenge because of data needs and conceptual complexity. One exception is the descriptive study of Bryant (1995), which used farmers, citizen associations, and local agencies to analyze peri-urban change in England. The fast evolving ABM approaches might soon be able to better deal with some of the current weaknesses of the A-C conceptual model.

\section{GUIDELINES FOR MODEL SELECTION}

All four models are applicable in the context of land change research. However, depending on (1) study aim and research questions, (2) the system under study, and (3) resources and data availability, one of the models might be most suitable for guiding research design. If the model choice does not match the characteristics of the study, the research may not be feasible, not lead to the anticipated results, or at least, be inefficient. Some guidelines for model selection are summarized in Table 1. These guidelines are based mostly on a combination of theoretical and practical considerations. Although some models have the potential to be of ubiquitous use, they may be unnecessarily complex for the system or research question addressed. Based on the conceptualization of the system, other models may not be suited to address the questions of interest or may have practical limitations in terms of data requirements.

\section{Study aim and research question}

Sometimes study aim and research questions favor a specific model. One major issue concerns the importance of knowledge about actors to achieve the study aim. If insights about the actors' decision making are not needed, the model DF-C is likely a good choice. If the goal of the research is to understand the causal chain from driving forces affecting actors and actors in turn affecting land change, then the model DF-A-C is likely a good choice. Research questions about the interactions among actors and drivers, including feedbacks, might best be served with a DFA-C model, whereas research focused on actor behavior and the role of decision making on land change might benefit from an A-C model. A second issue relates to the type of knowledge that should be generated. If exploration and hypothesis generation is the goal, the DF-C model is most appropriate. If understanding and unraveling causal relationships is the goal, the other three models are more appropriate. Furthermore, if the research is conducted in order to develop intervention measures (planning or policy), the models DFA-C and A-C are most promising since they help generate a solid understanding of the interactions of actors, driving forces (e.g., political driving forces), and land change. If projective studies and scenarios of alternative futures are the goal, operational models or trend extrapolations based on narratives are appropriate methods. Though all four conceptual models have the potential to be used in this way, most published research on scenarios is based on the DF-C model (e.g., Soares et al. 2002, Rounsevell et al. 2006).

\section{System under study}

Two issues are important in this context: geographical extent and system complexity. For the three models that include actors, interview data are generally necessary. These data are often time and labor intensive to obtain. The dependence on interviews restricts the application of the DF-A-C, DFA-C, and A-C models to rather limited spatial scales as well as short time scales. Of course, it is possible to base the parameterization on a limited sample of interviews by categorizing agents by their agent type. Subsequently, the data can be extrapolated based on data available for the larger study area (Castella et al. 2005, Valbuena et al. 2010). However, the uncertainty introduced by such methods is large. In contrast, the DF-C model is often applied to large areas (regions to continents or even the world) but can also be applied to small areas. The reliance on often rather easily available spatial data sets and the range of spatial resolution that may be used in the analysis makes the application of the DF-C model straightforward. System complexity, and especially the number of land covers and land uses studied, is another issue to consider. The DF-C and DF-A-C models allow 
Table 1. Guidelines for conceptual model selection, based on main model characteristics and practical limitations (DF - driving forces, $\mathrm{C}$ - land change, $\mathrm{A}$ - actors).

\begin{tabular}{|c|c|c|c|c|}
\hline & DF-C & DF-A-C & DFA-C & A-C \\
\hline \multirow[t]{4}{*}{ Study aim } & Exploration & $\begin{array}{l}\text { Understanding causal } \\
\text { chain driving forces- } \\
\text { actors-change }\end{array}$ & $\begin{array}{l}\text { Interactions among } \\
\text { actors and drivers of } \\
\text { land change, } \\
\text { including feedbacks }\end{array}$ & $\begin{array}{l}\text { Actor behavior and } \\
\text { decision making } \\
\text { resulting in land } \\
\text { change }\end{array}$ \\
\hline & $\begin{array}{l}\text { Generation of } \\
\text { hypotheses }\end{array}$ & $\begin{array}{l}\text { Identifying specific } \\
\text { combinations of driving } \\
\text { forces and actors that } \\
\text { lead to change }\end{array}$ & $\begin{array}{l}\text { Policy analysis and } \\
\text { intervention }\end{array}$ & $\begin{array}{l}\text { Interactions among } \\
\text { actors of land change, } \\
\text { including feedbacks }\end{array}$ \\
\hline & & & & $\begin{array}{l}\text { Policy analysis and } \\
\text { intervention }\end{array}$ \\
\hline & $\begin{array}{l}\text { Estimation of } \\
\text { parameters for } \\
\text { theoretical models }\end{array}$ & & & Social learning \\
\hline Geographical extent & Small to large & Small to medium & Small to medium & Small \\
\hline \multirow[t]{2}{*}{$\begin{array}{l}\text { Number of land covers } \\
\text { and land uses }\end{array}$} & Few to many & Few to many & $\begin{array}{l}\text { Only the ones that are } \\
\text { directly affected by } \\
\text { one driving forces- } \\
\text { actor system }\end{array}$ & $\begin{array}{l}\text { Only the ones that are } \\
\text { directly affected by the } \\
\text { actors' groups } \\
\text { considered in the A-C } \\
\text { model (e.g., farmers) }\end{array}$ \\
\hline & & & $\begin{array}{l}\text { Generally few similar } \\
\text { ones }\end{array}$ & $\begin{array}{l}\text { Generally few similar } \\
\text { ones (e.g., crops) }\end{array}$ \\
\hline \multirow[t]{3}{*}{ Type of data } & Potential drivers & Potential drivers & Potential drivers & $\begin{array}{l}\text { Actors' behavior and } \\
\text { interaction }\end{array}$ \\
\hline & Land change data & Land change data & $\begin{array}{l}\text { Actors' behavior and } \\
\text { actor interaction }\end{array}$ & Land change data \\
\hline & & $\begin{array}{l}\text { General characteristics } \\
\text { of actors }\end{array}$ & Land change data & \\
\hline
\end{tabular}

researchers to include a high number of unrelated land uses, including various agricultural land uses, various forest covers, various urban land uses, and types of protected land. Studying many different land uses and land covers with these models is possible because they do not require detailed knowledge about the interaction of actors and land use/land cover. However, the models DFA-C and A-C generally are limited to a single actor group (often farmers or urban residents) due to the high complexity of incorporating multiple interacting actor types (Benenson et al. 2002, Rindfuss et al. 2008). Therefore, these models are limited to the land uses and land covers that are directly affected by one single actor group (Matthews et al. 2007). 


\section{Resources and data availability}

The available data can also be important for model selection. Clearly, land change data are always necessary. However, if it is not possible to get data related to actor behavior and actor interaction (due to issues of privacy, cost, or feasibility related to the size of the study area), models DFA-C and A-C are not a reasonable option. If data on actors but not on their decision-making strategies are available, model DF-A-C might be a good choice. In situations without access or the possibility to collect data on actors, model DF-C might be the best choice.

\section{Methods applied}

The method used to establish the links between driving factors and land change is not a defining criterion for model selection. Each model can be studied with a range of methods, though certain methods and method combinations dominate in certain models. For example, in the DF-C model, regression analyses are very prevalent (Verburg 2009). Ordination techniques (Hietel et al. 2005) and combinations of regression analyses with interviews (Gellrich et al. 2008) have also been used. The other models tend to rely more on social science methods, including participatory methods (Castella et al. 2005, Özkaynak 2008), interviews (Overmars et al. 2007a), or economic theory (Balmann 1997, Parker et al. 2003, Ligtenberg et al. 2004). However, for the parameterization of the relations, statistical techniques may be used in all models, similar to the DF-C model. Young et al. (2006) present an overview of the methods for land change studies.

Two examples illustrate how one might use the guidelines for model selection presented in Table 1. In a project where the causal chain from driving forces to actors in proximate causes to land change is of interest, the DF-A-C model is the first choice. However, the table indicates that this model is not suited to policy analysis and social learning. If social learning is another important goal of this project, a combination of methods might be considered. The table also shows that for a project with a large study area, the DF-C model is likely the most appropriate model, whereas the use of the other models for large study areas faces practical problems.

\section{DISCUSSION AND CONCLUSIONS}

\section{What do we gain from explicitly conceptualizing the link between driving forces, actors, and change?}

In land change research, we need to choose a model of how land change is linked to driving forces and actors. Conceptualizing the links with the four proposed models has several potential benefits. The conscious choice of one model (or several models) certainly can help to focus research. It can make underlying assumptions more clear. It can therefore enhance clarity, especially in complex situations

(e.g., areas such as peri-urban regions that are experiencing several simultaneous processes of land change).

Furthermore, communication about research projects and their results can be enhanced with a clear declaration of the conceptual model used. The same is true for generalizing the findings beyond the individual project (e.g., meta-analysis; Geist and Lambin 2004, Keys and McConnell 2005, Rudel 2008). It is likely that results are best summarized and generalized on the level of research based on a specific model. It should, however, be noted that studies conducted by the same model but using different levels of (spatial) aggregation may still not be easily compared (Walsh et al. 1999, Veldkamp and Lambin 2001).

\section{Do we get closer to causality?}

The four models help to conceptualize the relation between driving forces, actors, and change. Regardless of which model is chosen, one of the core challenges in studies of land change is to determine not merely correlations but causal relationships between driving forces, actors, and land change. Causal relationships should be supported by theories. Clearly, no direct relationship can be established between the theories of land change discussed in the introduction and specific conceptual models. For example, von Thünen's agricultural land rent theory can be the basis for identifying driving forces that explain the location of agricultural land uses in a DF-C model. However, the same agricultural land rent theory can be the basis for describing actor behavior in an A$\mathrm{C}$ model, depending on the interest of the researcher or modeler. 
The organizational heuristic with four conceptual models presented in this paper is especially useful in the context of inductive theory development. One approach to move from correlations towards causalities is to formulate hypotheses based on statistical analyses (i.e., correlations) and test them further on with additional, independent data (e.g., Bürgi and Turner 2002). Another approach is to combine macro-level analyses with micro-level investigations and to consider scale dependencies of the analyses on both levels in the scaling procedures (Verburg et al. 2006a). Integrated modeling of decision-making and land dynamics and comparative studies and meta-analyses might offer additional insights (Lambin and Geist 2006). In other cases, it will be necessary to incorporate data sources such as expert interviews, narratives, and historical documents that are not usually considered in land change studies (e.g., Schneeberger et al. 2007). Still, not every proposed causation can be tested rigorously because the necessary data might be lacking and impossible to collect. In these cases, including circumstantial evidence and inferential reasoning might bear some potential to understand the system under study more accurately (Bürgi and Russell 2001).

\section{What is the benefit of using several conceptual models?}

Similar to the call for using multiple methods in land change science (Campbell et al. 2005) and support of multiple methods in a portfolio approach (Young et al. 2006), the use of more than one of the outlined models is a promising approach for complex research projects. A research project could be developed using several models sequentially or in parallel, analogous to the use of several methods promoted in Young et al. (2006).

Integrated models provide a good framework for the combination of two or more conceptual models, though many integrated models are based on a single conceptual model. Integrated models of land change consider the interactions and linkages between two or more components of a spatial system. For example, Gaube et al. (2009) combined an agentbased model, a GIS-based land use module, and a stock-flow model of carbon and nitrogen flows. The agent-based model represents the A-C conceptual model, whereas the GIS-based land use model represents primarily the DF-C model.
Both Castella and Verburg (2007) and Overmars et al. (2007a) compared the application of different conceptual models to the same case study. The results from the comparisons indicated that the lessons learned and the applicability of the results differed depending on the conceptual model chosen. At the same time, the results of the different models may inform each other and lead to an improved, complementary understanding of the land system studied.

Another advantage of combining different models may be the increased insight about how individual behavior scales up to generate patterns of land change. The cumulative result of many micro-level interactions studied with either the A-C or the DFA$\mathrm{C}$ models should correspond to macro-level patterns identified with the DF-C model. Thus, connecting micro-level and macro-level methods of analysis (as proposed by Coleman 1990) explicitly calls for better understanding the scale dependencies within the land system (Verburg et al. 2006b).

Land change research is especially demanding with respect to conceptualizations. We hope that the conceptual considerations outlined in this paper will help improve the scientific quality of individual studies as well as their potential contribution towards generic theories of land change. The diversity of the study approaches in the inherently interdisciplinary science of land change points out the challenges that scientists but also funding institutions face in trying to study, support, and disseminate insights about the dynamics and trajectories of land change.

Responses to this article can be read online at:

http://www.ecologyandsociety.org/vol15/iss4/art1/responses/

\section{Acknowledgments:}

We would like to thank two anonymous reviewers and the subject editor for their helpful comments.

\section{LITERATURE CITED}

Agarwal, C., G. M. Green, J. M. Grove, T. P. Evans, and C. M. Schweik. 2002. A review and assessment of land-use change models: dynamics 
of space, time, and human choice. Gen. Tech. Rep. NE-297. U.S. Department of Agriculture, Forest Service, Northeastern Research Station, Newton Square, Pennsylvania, USA.

Alig, R. J., J. D. Kline, and M. Lichtenstein. 2004. Urbanization on the US landscape: looking ahead in the 21 st century. Landscape and Urban Planning 69:219-234.

Angelsen, A. 1999. Agricultural expansion and deforestation: modelling the impact of population, market forces and property rights. Journal of Development Economics 58:185-218.

Balmann, A. 1997. Farm-based modelling of regional structural change: a cellular automata approach. European Review of Agricultural Economics 24:85-108.

Baudry, J., C. Laurent, C. Thenail, D. Denis, and F. Burel. 1999. Driving factors of land-use diversity and landscape pattern at multiple scales - a case study in Normandy, France. Pages 103-119 in R. Krönert, editor. Land-use changes and their environmental impact in rural areas in Europe. The Parthenon Publishing Group, Paris, France.

Benenson, I., I. Omer, and E. Hatna. 2002. Entitybased modeling of urban residential dynamics: the case of Yaffo, Tel Aviv. Environment and Planning B-Planning \& Design 29:491-512.

Bohnet, I. 2008. Assessing retrospective and prospective landscape change through the development of social profiles of landholders: a tool for improving land use planning and policy formulation. Landscape and Urban Planning 88:111 .

Bohnet, I., C. Potter, and E. Simmons. 2003. Landscape change in the multi-functional countryside: a biographical analysis of farmer decision-making in the English High Weald. Landscape Research 28:349-364.

Bolstad, P. V., W. Swank, and J. Vose. 1998. Predicting southern Appalachian overstory vegetation with digital terrain data. Landscape Ecology 13:271-283.

Boserup, E. 1965. The conditions of agricultural growth. Allen and Unwin, London, UK.
Brandt, J., J. Primdahl, and A. Reenberg. 1999.

Rural land-use and landscape dynamis - analysis of "driving forces" in space and time. Pages 81-102 in R. Krönert, J. Baudry, I. R. Bowler, and A. Reenberg, editors. Land-use changes and their environmental impact in rural areas in Europe. The Parthenon Publishing Group, Paris, France.

Briassoulis, H. 2000. Analysis of land-use change: theoretical and modeling approaches. The Web Book of Regional Science, West Virginia University. http://www.rri.wvu.edu/WebBook/Bria ssoulis/contents.htm.

Briassoulis, H. 2008. Land-use policy and planning, theorizing, and modeling: lost in translation, found in complexity? Environment and Planning B-Planning \& Design 35:16-33.

Browder, J. O., M. A. Pedlowski, R. Walker, R. H. Wynne, P. M. Summers, A. Abad, N. BecerraCordoba, and J. Mil-Homens. 2008. Revisiting theories of frontier expansion in the Brazilian Amazon: a survey of the colonist farming population in Rondonia's post-frontier, 1992-2002. World Development 36:1469-1492.

Bryant, C. R. 1995. The role of local actors in transforming the urban fringe. Journal of Rural Studies 11:255-267.

Bürgi, M., A. M. Hersperger, and N. Schneeberger. 2004. Driving forces of landscape change - current and new directions. Landscape Ecology 19:857-868.

Bürgi, M., and E. W. B. Russel. 2001. Integrative methods to study landscape changes. Land Use Policy 18:9-16.

Bürgi, M., and M. G. Turner. 2002. Factors and processes shaping land cover and land cover changes along the Wisconsin River. Ecosystems 5:184-201.

Caldas, M., R. Walker, E. Arima, S. Perz, S. Aldrich, and C. Simmons. 2007. Theorizing land cover and land use change: the peasant economy of Amazonian deforestation. Annals of the Association of American Geographers 97:86-110.

Campbell, D. J., D. P. Lusch, T. A. Smucker, and E. E. Wangui. 2005. Multiple methods in the study 
of driving forces of land use and land cover change: a case study of SE Kajiado District, Kenya. Human Ecology 33:763-794.

Castella, J. C., T. N. Trung, and S. Boissau. 2005. Participatory simulation of land-use changes in the northern mountains of Vietnam: the combined use of an agent-based model, a role-playing game, and a geographic information system. Ecology and Society 10(1):27. [online] URL: http://www.ecolog yandsociety.org/vol10/iss1/art27/.

Castella, J. C., and P. H. Verburg. 2007. Combination of process-oriented and patternoriented models of land-use change in a mountain area of Vietnam. Ecological Modelling 202:410420.

Chomitz, K. M., and D. A. Gray. 1996. Roads, land use, and deforestation: a spatial model applied to Belize. World Bank Economic Review 10:487512 .

Clifford, N. J. 2008. Models in geography revisited. Geoforum 39:675-686.

Coleman, J. S. 1990. Foundations of social theory. The Belknap Press of the Harvard University Press, Cambridge, Massachusetts, USA.

Darnhofer, I., W. Schneeberger, and B. Freyer. 2005. Converting or not converting to organic farming in Austria: farmer types and their rationale. Agriculture and Human Values 22:39-52.

Defrancesco, E., P. Gatto, F. Runge, and S. Trestini. 2008. Factors affecting farmers' participation in agri-environmental measures: a northern Italian perspective. Journal of A gricultural Economics 59:114-131.

de Groot, W. T. 1992. Environmental science theory: concepts and methods in a one-world, problem oriented paradigm. Elsevier Science Publishers, Amsterdam, The Netherlands.

Dendoncker, N., M. Rounsevell, and P. Bogaert. 2007. Spatial analysis and modelling of land use distributions in Belgium. Computers Environment and Urban Systems 31:188-205.

Fontaine, C. M., and M. D. A. Rounsevell. 2009.
An agent-based approach to model future residential pressure on a regional landscape. Landscape Ecology 24:1237-1254.

Fox, J., R. R. Rindfuss, S. J. Walsh, and V. Mishra, editors. 2003. People and the environment: approaches for linking household and community surveys to remote sensing and GIS. Kluwer Academic Publishers, Boston, Massachusetts, USA.

Gaube, V., C. Kaiser, M. Wildenberg, $\mathbf{H}$. Adensam, P. Fleissner, J. Kobler, J. Lutz, A. Schaumberger, J. Schaumberger, B. Smetschka, A. Wolf, A. Richter, and H. Haberl. 2009. Combining agent-based and stock-flow modelling approaches in a participative analysis of the integrated land system in Reichraming, Austria. Landscape Ecology 24:1149-1165.

Geist, H. J., and E. F. Lambin. 2002. Proximate causes and underlying driving forces of tropical deforestation. Bioscience 52:143-150.

Geist, H. J., and E. F. Lambin. 2004. Dynamic causal patterns of desertification. Bioscience 54:817-829.

Gellrich, M., P. Baur, B. H. Robinson, and P. Bebi. 2008. Combining classification tree analyses with interviews to study why sub-alpine grasslands sometimes revert to forest: a case study from the Swiss Alps. Agricultural Systems 96:124-138.

Gennaio, M. P. 2008. Political driving forces of urban change in the region Agglomeration Obersee. Dissertation ETH Zurich, Zurich, Switzerland.

Gennaio, M. P., A. M. Hersperger, and M. Bürgi. 2009. Containing urban sprawl - evaluating effectiveness of urban growth boundaries set by the Swiss Land Use Plan. Land Use Policy 26:224-232.

Geoghegan, J., L. Pritchard Jr., Y. OgnevaHimmelberger, R. Roy Chowdhury, S. Sanderson, and B. L. Turner II. 1998. Socializing the pixel and pixelizing the social. Pages 51-69 in People and pixels: linking remote sensing and social science. Committee on the Human Dimensions of Global Change and National Research Council, Washington, D.C., USA 
Geoghegan, J., S. C. Villar, P. Klepeis, P. M. Mendoza, Y. Ogneva-Himmelberger, R. R. Chowdhury, B. L. Turner, and C. Vance. 2001. Modeling tropical deforestation in the southern Yucatan peninsular region: comparing survey and satellite data. Agriculture Ecosystems \& Environment 85:25-46.

Hersperger, A. M., and M. Bürgi. 2007. Driving forces of landscape change in the urbanizing Limmat Valley, Switzerland. Pages 45-60 in E. Koomen, A. Bakeman, J. Stillwell, and H. Scholten, editors. Modelling land-use change. Springer, Dordrecht, The Netherlands.

Hersperger, A. M., and M. Bürgi. 2009. Going beyond landscape change description: quantifying the importance of driving forces of landscape change in a Central Europe case study. Land Use Policy 26:640-648.

Hersperger, A. M., and M. Bürgi. 2010. How do policies shape landscapes? Landscape change and its political driving forces in the Limmat Valley, Switzerland 1930-2000. Landscape Research. In press.

Herzon, I., and M. Mikk. 2007. Farmers' perceptions of biodiversity and their willingness to enhance it through agri-environment schemes: a comparative study from Estonia and Finland. Journal for Nature Conservation 15:10-25.

Hietel, E., R. Waldhardt, and A. Otte. 2005. Linking socio-economic factors, environment and land cover in the German Highlands, 1945-1999. Journal of Environmental Mangement 75:133-143.

Irwin, E. G., and J. Geoghegan. 2001. Theory, data, methods: developing spatially explicit economic models of land use change. Agriculture, Ecoystems \& Environment 85:7-24.

Keys, E., and W. J. McConnell. 2005. Global change and the intensification of agriculture in the tropics. Global Environmental Change-Human and Policy Dimensions 15:320-337.

Lambin, E. F., and H. J. Geist, editors. 2006. Landuse and land cover change: local processes and global impacts. Springer, Berlin, Germany.

Lambin, E. F., H. J. Geist, and E. Lepers. 2003. Dynamics of land-use and land-cover change in tropical regions. Annual Review of Environment and Resources 28:205-241.

Lambin, E. F., H. Geist, and R. R. Rindfuss. 2006. Introduction: local processes with global impacts. Pages 1-8 in E. F. Lambin and H. Geist, editors. Land-use and land-cover change: local processes and global impacts. Springer, Berlin, Germany.

Lambin, E. F., B. L. Turner, H. J. Geist, S. B. Agbola, A. Angelsen, J. W. Bruce, O. T. Coomes, R. Dirzo, G. Fischer, C. Folke, P. S. George, K. Homewood, J. Imbernon, R. Leemans, X. Li, E. F. Moran, M. Mortimore, P. S. Ramakrishnan, J. F. Richards, H. Skånes, W. Steffen, G. D. Stone, U. Svedin, T. A. Veldkamp, C. Vogel, and J. Xu. 2001. The causes of land-use and land cover change: moving beyond the myths. Global Environmental Change 11:261-269.

Ligtenberg, A., M. Wachowicz, A. K. Bregt, A. Beulens, and D. L. Kettenis. 2004. A design and application of a multi-agent system for simulation of multi-actor spatial planning. Journal of Environmental Management 72:43-55.

Loibl, W., and T. Toetzer. 2001. Modeling growth and densification processes in suburban regions simulation of landscape transition with spatial agents. Pages 553-563 in 4th International Symposium on Environmental Software Systems. Banff, Alberta, Canada.

Manson, S. M. 2001. Simplifying complexity: a review of complexity theory. Geoforum 32:405414.

Manson, S., and D. O'Sullivan. 2006. Complexity theory in the study of space and place. Environment and Planning A 38:677-692.

Matthews, R. B., N. G. Gilbert, A. Roach, J. G. Polhill, and N. M. Gotts. 2007. Agent-based landuse models: a review of applications. Landscape Ecology 22:1447-1459.

Merchant, C. 1990 . The realm of social relations: production, reproduction and gender in environmental transofrmations. Pages 672-684 in B. L. Turner II, W. C. Clark, R. W. Kates, J. F. Richards, J. T. Mathews, and W. B. Meyer, editors. The earth as transformed by human action: global and regional changes in the biosphere over the past 300 years. Cambridge University Press, Cambridge, UK. 
Monticino, M., M. Acevedo, B. Callicott, T. Cogdill, and C. Lindquist. 2007. Coupled human and natural systems: a multi-agent-based approach. Environmental Modelling \& Software 22:656-663.

Moran, E. F., A. Siqueira, and E. Bondizio. 2003. Household demographic structure and its relationship to deforestation in the Amazon Basin. In J. Fox, R. R. Rindfuss, S. J. Walsh, and V. Mishra, editors. People and the environment: approaches for linking household and community surveys to remote sensing and GIS. Kluver Academic Publishing, Boston, Massachusetts, USA.

Overmars, K. P., W. T. de Groot, and M. G. A. Huigen. 2007a. Comparing inductive and deductive modeling of land use decisions: principles, a model and an illustration from the Philippines. Human Ecology 35:439-452.

Overmars, K. P., P. H. Verburg, and T. Veldkamp. 2007b. Comparison of a deductive and an inductive approach to specify land suitability in a spatially explicit land use model. Land Use Policy 24:584-599.

Özkaynak, B. 2008. Globalisation and local resistance: alternative city developmental scenarios on capital's global frontier the case of Yalova, Turkey. Progress in Planning 70:45-97.

Pahari, K., and S. Murai. 1999. Modelling for prediction of global deforestation based on the growth of human population. Journal of Photogrammetry and Remote Sensing 54:317-324.

Pan, W. K. Y., and R. E. Bilsborrow. 2005. The use of a multilevel statistical model to analyze factors influencing land use: a study of the Ecuadorian Amazon. Global and Planetary Change 47:232-252.

Parker, D. C., T. Berger, and S. M. Manson, editors. 2002. Agent-based models of land-use and land-cover change. LUCC Focus 1 Office, Indiana University, Bloomington, Indiana, USA.

Parker, D. C., A. Hessl, and S. C. Davis. 2008. Complexity, land-use modeling, and the human dimension: fundamental challenges for mapping unknown outcome spaces. Geoforum 39:789-804.
Parker, D. C., S. M. Manson, M. A. Janssen, M. J. Hoffmann, and P. Deadman. 2003. Multi-agent systems for the simulation of land-use and landcover change: a review. Annals of the Association of American Geographers 93:314-337.

Perz, S. G., and R. T. Walker. 2002. Household life cycles and secondary forest cover among small farm colonists in the Amazon. World Development 30:1009-1027.

Rabin, M. 1998. Psychology and economics. Journal of Economic Literature 36:11-46.

Richards, J. F. 1990. Land transformation. Pages 163-178 in B. L. Turner II, W. C. Clark, R. W. Kates, J. F. Richards, J. T. Mathews, and W. B. Meyer, editors. The earth as transformed by human action: global and regional changes in the biosphere over the past 300 years. Cambridge University Press, Cambridge, UK.

Rindfuss, R. R., B. Entwisle, S. J. Walsh, L. An, N. Badenoch, D. G. Brown, P. Deadman, T. P. Evans, J. Fox, J. Geoghegan, M. Gutmann, M. Kelly, M. Linderman, J. Liu, G. P. Malanson, C. F. Mena, J. P. Messina, E. F. Moran, D. C. Parker, W. Parton, P. Prasartkul, D. T. Robinson, Y. Sawangdee, L. K. Vanwey, and P. H. Verburg. 2008. Land use change: complexity and comparisons. Journal of Land Use Science 3:1-10.

Rindfuss, R. R., S. J. Walsh, B. L. Turner, J. Fox, and V. Mishra. 2004. Developing a science of land change: challenges and methodological issues. Proceedings of the National Academy of Sciences of the United States of America 101:13976-13981.

Rounsevell, M. D. A., I. Reginster, M. B. Araujo, T. R. Carter, N. Dendoncker, F. Ewert, J. I. House, S. Kankaanpaa, R. Leemans, M. J. Metzger, C. Schmit, P. Smith, and G. Tuck. 2006. A coherent set of future land use change scenarios for Europe. Agriculture Ecosystems \& Environment 114:57-68. 
Rudel, T. K. 2008. Meta-analyses of case studies: a method for studying regional and global environmental change. Global Environmental Change-Human and Policy Dimensions 18:18-25.

Rudel, T. K. 2009. How do people transform landscapes? A sociological perspective on suburban sprawl and tropical deforestation. American Journal of Sociology 115:129-154.

Sabatier, P. A. 1998. The advocacy coalition framework: revisions and relevance for Europe. Journal of European Public Policy 5:98-130.

Schaldach, R., and J. A. Priess. 2008. Integrated models of the land system: a review of modelling approaches on the regional to global scale. Living Reviews in Landscape Research 2. [online] URL: http://landscaperesearch.livingreviews.org/Articles/ 1rlr-2008-1/.

Schneeberger, N., M. Bürgi, A. M. Hersperger, and K. C. Ewald. 2007. Driving forces and rates of landscape change as a promising combination for landscape change research - an application on the northern fringe of the Swiss Alps. Land Use Policy 24:349-361.

Seabrook, L., C. McAlpine, and R. Fensham. 2006. Cattle, crops and clearing: regional drivers of landscape change in the Bridglow Belt, Queensland, Australia, 1840-2004. Landscape and Urban Planning 78:373-385.

Soares, B. S., G. C. Cerqueira, and C. L. Pennachin. 2002. DINAMICA - a stochastic cellular automata model designed to simulate the landscape dynamics in an Amazonian colonization frontier. Ecological Modelling 154:217-235.

Thapa, G. B., and G. Rasul. 2006. Implications of changing national policies on land use in the Chittagong Hill Tracts of Bangladesh. Journal of Environmental Management 81:441-453.

Turner, B. L., and P. Robbins. 2008. Land-change science and political ecology: similarities, differences, and implications for sustainability science. Annual Review of Environment and Resources 33:295-316.

Turner II, B. L., E. F. Lambin, and A. Reenberg. 2007. The emergence of land change science for global environmental change and sustainability.
Proceedings of the National Academy of Sciences of the United States of America 104:20666-20671.

Valbuena, D., P. H. Verburg, and A. K. Bregt. 2008. A method to define a typology for agent-based analysis in regional land-use research. Agriculture Ecosystems \& Environment 128:27-36.

Valbuena, D., P. H. Verburg, A. K. Bregt, and A. Ligtenberg. 2010. An agent-based approach to model land use change at a regional scale. Landscape Ecology 25:185-199.

VanWey, L. K., E. Ostrom, and V. Meretsky. 2005. Theories underlying the study of humanenvironment interactions. Pages 23-56 in E. Moran and E. Ostrom, editors. Seeing the forest and the trees: human-environment interactions in forest ecosystems. The MIT Press, Cambridge, Massachusetts, USA.

Veldkamp, A., and E. F. Lambin. 2001. Predicting land-use change. Agriculture, Ecoystems \& Environment 85:1-6.

Verburg, P. H. 2009. Land use change: science, policy, and management. Environment and Planning B-Planning \& Design 36:569-570.

Verburg, P. H., K. Kok, R. G. J. Pontius, and A. Veldkamp. 2006a. Modeling land-use and landcover change. Pages 117-135 in E. F. Lambin and H. J. Geist, editors. Land-use and land-cover change. Springer, Berlin, Germany.

Verburg, P. H., P. Schot, M. Dijst, and A. Veldkamp. 2004. Land use change modelling: current practice and reseach priorities.

GeoJournal 61:309-324.

Verburg, P. H., A. Veldkamp, and M. D. A. Rounsevell. 2006 b. Scenario-based studies of future land use in Europe. Agriculture, Ecoystems \& Environment 114:1-6.

Walker, R. 2001. Urban sprawl and natural areas encroachment: linking land cover change and economic development in the Florida Everglades. Ecological Economics 37:357-369.

Walker, R. 2004. Theorizing land-cover and landuse change: the case of tropical deforestation. International Regional Science Review 27:247270. 
Walker, R., J. Browder, E. Arima, C. Simmons, R. Pereira, M. Caldas, R. Shirota, and S. de Zen. 2009. Ranching and the new global range: Amazonia in the 21st century. Geoforum 40:732745.

Walker, R., S. Perz, M. Caldas, and L. G. T. Silva. 2002. Land use and land cover change in forest frontiers: the role of household life cycles. International Regional Science Review 25:169199.

Walker, R., and W.Solecki. 2004. Theorizing landcover and land-use change: the case of the Florida Everglades and its degradation. Annals of the Association of American Geographers 94:311-328.

Walsh, S. J., T. P. Evans, W. F. Welsh, B. Entwisle, and R. R. Rindfuss. 1999. Scale-dependent relationships between population and environment in northeastern Thailand. Photogrammetric Engineering \& Remote Sensing 65:97-105.

Walsh, S. J., J. P. Messina, K. A. Crews-Meyer, R. E. Bilsborrow, and W. K. Y. Pan. 2002. Characterizing and modeling patterns of deforestation and agricultural extensification in the Ecuadorian Amazon. Pages 187-214 in S. J. Walsh and K. A. Crews-Meyer, editors. Linking people, place, and policy: a GIScience approach. Kluver Academic Publishers, Boston, Massuchusetts, USA.

Wilson, G. A. 2008. From "weak" to "strong" multifunctionality: conceptualizing farm-level mulitfunctional transitional pathways. Journal of Rural Studies 24:367-383.

Young, O. R., E. F. Lambin, F. Alcock, H. Haberl, S. I. Karlsson, W. J. McConnell, T. Myint, C. Pahl-Wostl, C. Polsky, P. S. Ramakrishnan, H. Schroeder, M. Scouvart, and P. H. Verbrug. 2006. A portfolio approach to analyzing complex humanenvironment interactions: institutions and land change. Ecology and Society 111(2):31. [online] URL: http://www.ecologyandsociety.org/vol11/iss2/ $\underline{\operatorname{art} 31 / .}$. 